\title{
Strategies of the Pay-TV in Government Administration
}

\author{
Fanbin Zeng (Corresponding author) \\ College of Journalism and Communication, Jinan University, Guangzhou 510632, China \\ E-mail: zengfanbin@vip.sina.com \\ Jinkai Zhang \\ College of Journalism and Communication, Jinan University, Guangzhou 510632, China \\ E-mail: 453619455@qq.com
}

$\begin{array}{ll}\text { Received: August 27, } 2012 & \text { Accepted: September 4, } 2012 \quad \text { Online Published: September 21, } 2012 \\ \text { doi:10.5430/bmr.v1n4p26 } & \text { URL: http://dx.doi.org/10.5430/bmr.v1n4p26 }\end{array}$

This Project was financed by 2012 Humanities and Social Science Youth Foundation of the Ministry of Education of China (Grant Number:12YJC860052; Grant Title: Effect of Time Spent Online and Patterns of internet use on Real-life Political Participation: Based on Empirical Study on Internet Users in Guangzhou)

\begin{abstract}
China's radio and television has always been an industry with strong policy, as a field of which the government strictly controls. At present, the special status of broadcast industry which should take account for both public interests and marketization is affected by the policies due to the nature of institution and enterprise management. Digital pay-TV as a part of broadcast industry cannot be exclusive. The government administration is defined as "a series of management and regulation behaviors which legal regulatory agencies are relatively independent as well taken by administrators (mainly enterprise) according to certain laws and regulations". The purpose of such restriction is to overcome market failures to maintain a favorable environment for a normal economic development. Government administration of digital pay-TV refers to government manage and control the premium channels in the means of economy, legislation, and administration in order to overcome or compensate the failure of market mechanism in resource allocation to ensure the reasonable allocation of market interests. Government's role is to create a more rational policy environment strengthening the management and standard to the market, increasing the intensity of macroeconomic regulation, to create a favorable external environment for premium channels. However, the administration is not so satisfying that in the following it will be analyzed.
\end{abstract}

Keywords: Government Administration, Pay-TV, Strategy, Policy

\section{China's Government Administration to the Pay-TV}

Government administration tools can be divided into indirect regulation and direct regulation. Indirect regulation is that regulation implement through the judicial process while direct regulation which consists of economic regulations and social regulations is to implement through administration department. In short, the approaches mean nothing more than legal means, administrative means and economical means all over the world. The State Administration Radio, Film and Television (SARFT) is the main administration in China. Currently, administrative means is the main one, basically relying on the policies. There are several government regulations of digital pay-TV, among policies and regulations on broadcast television and cable television.

Since China's digital pay-TV born in 2003, the SARFT with some relevant departments has issued a series of rules and regulations, such as Responsibilities of Radio, Film and Television, Interim Measures for Management of Cable Digital Pay-TV Channels (Trial), Views on Promoting the Development of Broadcast Industry, Requirements for Production of Management of Broadcasting Program, Views on Promoting the Operative Industrialization of Cable Digital Pay-TV, Policies to Encourage the Development of Digital TV Industry, etc. Among them, Interim Measures for Management of Cable Digital Pay-TV Channels (Trial) formulates the operation, program content, service, and supervision of pay-TV, which guided and promoted initial pay-TVs. Bid for the Integrated Service organizations of the National Broadcasting Cable Digital Pay-TV, relaxed the scope of establishing a national integrated operating 
agency for pay channels. Overall, the intentions of series of policies formulated by the departments are as follow:

\subsection{Promoting the Development of Pay-TV Channels}

The SARFT regards cable digital TV as a business to carry out. Pay channels are the main driving forces while other value-added businesses of cable digital TV are not yet mature. In the early stage of digital TV, institutions are encouraged to provide or participant in pay channel cooperation which dominate the channel resource and content, like China Central Television (CCTV) and provincial TV stations.

In 2003, in the Responsibilities of Radio, Film and Television, the SARFT pointed out "launch a number of sets of pay-TV as a breakthrough, to develop the online audio, video and value-added services, to establish a new preliminary mode of pay-TV" and "strengthen the norm and guidance to promote the development of pay-TV rapidly and healthily". In 2003, Interim Measures for Management of Cable Digital Pay-TV Channels (Trial) clearly pointed out the purpose is "to promote and regulate the healthy development of cable digital pay-TV, and maintain the operational subjects and users' rights, according to Radio and TV Ordinance". In July, 2005, the SARFT issued Views on the Conversion of Cable Digital TV, further promoting the overall conversion of digital pay-TV, and pointed out the "pilot units attaching more importance to the promotion of premium channel, video on demand, interactive TV and high definition TV when conversing". At the same time, the SARFT made a further request, "in accordance with the provisions that in 180 days since the approval, stations complete the preparation and sent the complete program signal qualifying standards to the integrated service organizations approved by the SARFT", due to the problem that some cities did not timely launch the digital pay channel when they had been approved. In January 1, 2008, the State Council General Office announced the First Document in the process of development called by the industry, Several Policies to Encourage the Development of Digital TV Industry, made by six ministries. The document stated seven aspects of the industry, such as development goals, optimizing investment environment, strengthening tax preference, promoting technical progress, fostering and regulating the market, promoting the triple play, strengthening the intellectual property protection. This policy provides an opportunity for private capital to enter the digital pay-TV field. Due to the positive attitude, to July, 2009, there are 142 sets of pay-TV with 39 sets of pay-radio approved by the SARFT, from the data of the SARFT, divided into national broadcast and the provincial. In seven years or so, national digital pay-TV has developed from 20 to over 140 sets, while there are over 240 provinces and regions carrying out the sales of premium channels.

\subsection{Regulating the Content Strictly}

Since the development of pay-TV, some relevant departments have regulated it. The idea of regulation is to regulate the content strictly. Interim Measures for Management of Cable Digital Pay-TV Channels (Trial) provides that "start-up corporations take responsibility for the content, in the way of examining before broadcasting and relaying". The prohibited contents are as follow:

(a) against the basic principles established by the Constitution; (b) harm national unity, sovereignty and territorial integrity; (c) disclose state secrets, endanger state security or harm national honor and interests; (d) incite ethnic hatred, ethnic discrimination, undermine national unity, or infringe upon national customs; (e) promote the cult of superstition; (f) disrupt the social orders or undermine social stability; (g) propagate obscenity, gambling, violence, or subornation; (h) insult or slander others, infringe upon the legal rights and interests; (i) harm social ethics or national cultural traditions; $(j)$ other contents prohibited by laws or regulations.

Currently, there is no difference between the content access policies of pay channels and free channels. Adult and gambling channels are the earning pillars of the industry abroad, but in China, these are the minefields. There is only five percent of the gap between pay and free channels in the proportion of introducing the offshore program, which apparently unable to reflect the particularity of the policy.

In addition, the SARFT formulates that "commercial advertisements are prohibited in the program except advertising to sale premium channels". For instance, in 2007, the SARFT issued Notification to the Violation of Nine Pay-TV Channels like Cruise Tours. The notification said:

According to the monitor, Cruise Tours operated by the Guangdong Southern Media Group, which professional programs is less than $90 \%$ of the broadcast, presents a large number of advertising programs, and analog broadcast on Guangdong Net, Yangjiang Net and Heyuan Net; Happy Shopping broadcasts on Guangdong Net, Guangzhou Net, Heyuan Net; Liyuan of Henan TV made an analog broadcast on Zhoukou Net; Channel Dressy of Jiangsu TV broadcasts commercials; Time Travel, Era Fashion of Tianjin TV, Film of Guizhou TV, Game, Fun and other channels of Liaoning TV take advantage of the ways of Introduction, recommendation, appreciation, learning English, etc., disguising broadcasting movies and television programs. 
The behavior of the nine channels above, as a serious violation of Interim Measures for Management of Cable Digital Pay-TV Channels (Trial). Article III of the Measures provides that pay channels "broadcast and transmit in cable digital ways, and users should pay apart for professional programs". Article 21 stipulates, "Pay channel programs should be consistent with professional and object-oriented requirements, which broadcast no less than $90 \%$ of the total broadcast time". Article 22 stipulates, "Channels should not broadcast movies without permission". Article 25 stipulates, "Pay channels should not broadcast commercials other than sell premium channels". According to the article 41 (b), (c), (d), (g) of the Measures provided, warning Guangdong Southern Media Group and Tianjin, Liaoning, Henan, Guizhou TV Stations; nine premium channels are ordered to stop the violations immediately, should not broadcast advertising programs, should not broadcast movie programs, and should not broadcast in analog form. Professional and object-oriented programs should not be broadcasted less than $90 \%$. In five days relevant channels should complete the rectification. If refuse to correct or rectify unqualifiedly, relevant channels will be suspended or even be revoked the license. Ordering the Cable Networks of Guangdong Province, Yangjiang, Heyuan, Zhoukou City, immediately stop the violations of using the analog transmission to access to pay channels.

Else, in January 14, 2010, the SARFT decided to withdraw English Learning of Jiangsu TV and Fun of Liaoning TV, which are both pay-TV channels, because these two channels violate to broadcast a large number of shopping programs, seriously violate the Measures, also in violation of provisions issued by the SARFT that in addition to the approved shopping channels or in a special time by filing, other analog, digital or premium channels should not broadcast shopping programs.

\subsection{Diversity of Capital Admittance}

Since the end of 2003, the government has tried to promote industrial upgrading by attracting domestic capital. The SARFT relaxed industrial policies, and promulgated five provisions about Sino-foreign cooperative business and Sino-foreign joint venture such as Opinions to Promote the Development of Radio, Film and Television Industry, Requirements of Radio and Television Program Production and Management. The threshold of broadcast separation system, social production companies which enter the television market is continuing lower, attracted a lot of enthusiasm of capitals. However, in November, 2003, the SARFT released the Measures, which provides that prohibiting the establishment of joint ventures, Sino-foreign cooperative, foreign sole proprietor to start up, broadcast, integrate, transmit, access and other businesses; offshore movies, TV series and cartoon should not exceed 30\% of the total; offshore radio and television programs are cancelled in any form. But allowing organizations which the registered capital owns more than 15 million RMB and net assets owns more than 3 million RMB without foreign funds background to participate in cooperation of pay channels, are not entitled to start up one. The diversity of domestic and foreign investment reflects the state ensuring ideological security, which intent to prevent the absolute control of foreign capital.

It's more obvious in the following policies. In 2004, Views to Promote the Development of Radio, Film and Television Industry promulgated the central government, provinces and provincial capitals, municipalities with independent planning status are the mainstays of starting up pay-TV, allowing qualified radio and television companies, state-owned institutions which own resource advantages, and other eligible institutions to involve the formation and market-oriented operation of the companies. The Views pointed out that the absorption of capital to reform shareholding system should ensure that state-owned capital controls the holdings. The government further defined this in subsequent item: no less than $51 \%$ of the shares are owned by the state-owned capital, thus private capital have a stake no more than $49 \%$. In June, 2004, the Views began to encourage the digital TV industry to absorb the funds of the state-owned and state holding enterprises, promote users to access to service organizations, and further stressed that the broadcast sector should maintain an actual control. (Zhao Fei, 2011)

Later the policies relaxed the funds. In 2005, the SARFT issued Interim Provisions of the Enterprise Management of Joint Venture, Cooperation in Radio and Television Program Production, to allow the establishment of Sino-foreign joint ventures. The Provisions set that domestic radio and television companies with foreign capital in China can be a joint venture to set up specializing in or engaging in radio and television program production and distribution businesses. But it clearly prohibited the wholly foreign-owned radio and television enterprises accessing to the industry in China, meanwhile prohibited private equity funds and other financial investors without qualifications from participating in the shares of the domestic broadcast companies. The new law also reduced the requirements of foreign capitals accessing to large state-owned media group. Previously, Viacom and Shanghai Media Group signed a joint plan. The long-awaited regulation provided a formal policy basis to the existing joint venture agreements. Zhu Hong, the secretary of the SARFT Regulation Department, said the SARFT hoped to lower the threshold so that private enterprises would promote the development of cultural industries with the state-owned enterprises in China. In April, 2005, the General Office of the SARFT forwarded on Decisions of Non-public Capital into the 
Cultural Industries, a notice that non-public capital could invest televisions in music, technology, sport, entertainment programming. This notice more explicitly provided the threshold of the capital accessing to the broadcast industry. The scientific and advanced television production experiences and the ideas of foreign capitals will play a positive role in promoting the quality of programs to improve the digital pay-TV channels.

In January, 2008, the National Development and Reform Commission, Ministry of Science and Technology, Ministry of Finance, Ministry of Information Industry, State Administration of Taxation, the SARFT and other six ministries jointly issued Policies to Encourage the Development of Digital TV Industry, clearly "support enterprises related to digital TV through the listing of the bond issue, allotment of shares and seasoned equity offering of listed companies to raise funds, to increase the input of the digital TV industry, to encourage financial institutions on the principle of science, prudence, and risk control, support the digital TV network and infrastructure platform, and further provide financial services for the development of digital TV industry".

\subsection{Explicitly Protecting Users' Rights and Interests}

In 2003, the Measures clearly defined users voluntarily choose and order the premium channels without any force; if users apply for accessing to premium channels, the service organizations should provide timely services, to ensure that users can receive premium channels in accordance with published service standards. Unless users do not pay for the fees or other legitimate reasons, the service organizations should not refuse, delay or interrupt, suspend to provide services; if users require to receive the list of charges, the service organizations should provide the list free of charge; users have the right to complain about illegal violations of the service organizations to radio and television administrative departments, and departments at all levels should timely dispose. Later Bid for the Integrated Service organizations of the National Broadcasting Cable Digital Pay-TV provides that "pay channel prices should be in accordance with the Price Law and Repeated Letters of the General Office of the State Planning Commission on Pay-TV and Video on Demand Service Charges, based on factors including cost, consumption level and marketing strategy, and reported to the local price departments to record". In 2009, the SARFT issued Notice of Construction and Management Advices of TV Shopping Channels to "establish and perfect the consumer protective system. Broadcasting agencies running TV shopping channels should strengthen the management of enterprise holdings and universal service obligations, asking shopping companies to increase market awareness, taking effective measures to protect the interests of consumers. Shopping companies should make a commitment that consumers can return the goods within a certain period after receipt. The goods qualified can be returned unconditionally and compensate the consumer's losses in accordance to the regulations". These relevant rules and regulations, clearly protect users' interests, and ensure that when their rights have been violated, they could receive a number of compensations.

\section{The Influences of Government Administration in China}

\subsection{Promoting the corporatization of Pay-TV Channels}

Currently, some premium channels are run by media groups or TV stations in the way of setting a company. In this way broadcast system is fully responsible for the operation. Differed from traditional channels, these channels are no longer sponsored by the stations. The CCTV sets up the Fengyun Communication Co., Ltd., dedicated to the production and integration of pay channels. Sets of pay channels offered by CCTV are completed by the company. The integrated planning and full development of the Beijing platform of digital television programs are implemented by Beijing Media Digital Corporation, the company launched by Beijing North Media Group Limited, the major shareholders include Beijing North Media Group Co., Ltd., Beijing People's Broadcasting Station, Beijing TV Station, Beijing Gehua Cultural Development Group, Beijing Gehua Cable TV Network Co., Ltd. Channel Dressy is operated by a new joint-stock company established by Jiangsu Radio and Television and Jiangsu Digital TV Co., Ltd. The first step is to launch Channel Dressy, later turn to other channels.

\subsection{Promoting the Co-operation of Pay-TV Channels and Social Institutions}

The Measures stipulates that social institutions can participate in the operation of pay channels, and social capital participates in the channel construction. On the one hand, it ensures a large number of funds to run early premium channels. On the other hand, it, which is the choice of a large number of pay channels, lays the foundation for the open content of pay channel programs, the expansion of channel derivatives and the promotion of market-oriented channels. For example, Auspicious Shopping launched by Jilin Television Tower and Television Shopping Network (TVSN) is produced in Shanghai. Jilin TV is responsible for program planning and broadcasting while the corporation provides logistics supports. Auto of Chongqing TV is cooperated with the Stellar Group DFI Digital Media Limited, which participates in content production and channel management. 


\subsection{Limiting a number of Channels}

Some channels are subject to national policy that is difficult to develop, such as Chinese first lottery TV channels--Happy Color ---is found by Shanghai digital pay-TV platform in June, 2005. Happy Color is founded by the Shanghai Media Group, Shanghai Media Interactive TV, as well as D set Network Systems Co., Ltd., Shanghai Lottery Center and Shanghai Sports Lottery Management Center.

In November 14, 2003, the SARFT issued the Measures. Happy Color should follow the Measures to carry out day-to-day operational activities. First of all, the Measures provides digital channels cannot have a foreign background, and therefore has a great influence on raising funds, so that the financial capacity of the channel has been extremely limited. Secondly, Happy Color broadcasting publicly needs a license permitted by the SARFT, which is valid for three years. Without the approval, continuous cessation of operation lasting for more than 7 days or stopping for more than 15 days cumulatively, it is considered to be terminated. In order to ensure that the license is valid, Happy Color must ensure that update lottery professional programs for more than two hours every day. In order to retain this license, the channel will have to spend a considerable manpower, material resources and financial resources.

The Measures provides that gambling is prohibited in the pay channels. As the incomplete policies and regulations, what the scope of the lottery industry is, what kind of gambling is, are not clear. In order to avoid unnecessary errors, many programs now are limited in the production link. In accordance with the requirements of the Measures, digital pay channels must comply with the requirements of the specialization, object-oriented, broadcasting for no less than $90 \%$ of the total. As a non-TV drama premium channels, Happy Color is prohibited to transmit movies and TV dramas. Broadcasting offshore radio and television channels in any form are prohibited while premium channels should not broadcast commercials other than advertising to sell premium channels. Happy Color is distressed by program production and sources, as well as profitability.

In addition, due to the limited number of viewers, audiences cannot watch other channels while watch a certain one. The main source of TV funds is advertisement. While advertiser's value most is the ratings, there are conflicts of interests between the traditional open TV channels and digital pay channels and among the premium channels. In order to ensure the ratings of open TV channels, Shanghai Media Group makes little effort to promote digital pay channels, or will it as open-channel programs. Thus it results in a generally unattractive digital pay channel programs, along with Happy Color.

\section{Government Administrations of the United States, Britain, Japan}

The pay-TV government administrations of the United States, Britain, and Japan subordinate to their television government administrations. To this end, we introduce in the television government administrations of the United States, the Britain, and the Japan.

\subsection{The Federal Communications Commission (FCC)}

The FCC, is the mainly independent government administrative agency for U.S. telecommunications, which the main task is to deal with interstate telecommunications business under the jurisdiction involving traditional broadcasting television, cable television, satellite $\mathrm{TV}$, and the vast majority of the developing video technologies (such as digital television, multimedia network transmission, etc.). It also includes telephone, telegraph, etc., except the audio-visual facilities running on the telecommunications network. The FCC, which the predecessor is the Federal Radio Commission, is based on the 1934 Communications Act. It is directly accountable to the Parliament (mainly establishes and controls the regulatory rules by law, submits annual reports, developing and strategic plans and annual budgets to the Congress.), the trial of the NBC and CBS appealing the United States government establishing its constitutionality in 1943. (NBC and CBS v. United States, 319 U.S. $190<1943>$ ) The Congress is to fulfill the authority of various types of examination and approval, including members of the Committee and other matters, to assess the job performance, to decide on the major reforms and related legislations. In 1983, the Congress abolished the permanent reauthorization of its legal powers, accrediting it every two years. Thus, the dominance of the Congress is further strengthened. In the 1980s, the Congress got more power, and in the 1990s the trend remains the same. A distinguishing mark is the U.S. 1996 Telecommunications Act. Surely there are many other factors affecting the FCC, such as the White House, industry lobby groups, the FCC internal political structure and the control opinions. (Robert J. Spitzer, 1993) However, the Congress and the Federal Supreme Court undoubtedly play the crucial roles.

The members of the Federal Communications Commission (five people since 1983, including a Chairman), are nominated by the President and approved by the Senate for a term of five years, which staffs from the same political 
party shall not be more than three. The FCC includes six bureaus (Executive Bureau, Consumption and Governmental Affairs Bureau, the International Bureau, Mass Media Bureau, Wireless Communications Bureau, Cable Competition Bureau) and 10 offices (Administrative Law Examination Office, Communications Office of Business Opportunities, Engineering and Technology Office, General Counsel Office, the Chief Inspector Office, the Legislative Affairs Office, the Managing Director Office, Media Liaison Office, Plan and Policy Office, Labor and Social Security Office).

In the field of wireless TV broadcast, the FCC focuses on issuing, continuing, updating, revoking and suspending the license, which is valid for eight years. Field in the cable, the 1984 Cable Communications Policy Act formally established the jurisdiction of the FCC, but the license is managed by the regional government, which the main business is to make local government guiding principles, standards, procedures and service regulations in accordance with the law to control the sizes and contents of the cable television companies, including the number of users. (Jin Guanjun \& Zhen Han, 2007)

The rules, regulations and policies of the FCC materially affect the terms, conditions and profits of the operations of telecommunications service providers. The U.S. Telecommunications Act gives the great flexibility to the FCC, to develop new rules, regulations and policies in accordance with the public interests. While accepting the court's scrutiny, the professional organization is usually qualified other than the infringement against proceedings or impartiality. (Patrick Parsons \& Robert Friedan)

The FCC is aimed at protecting and promoting the constitutional rights of freedom speech. The First Amendment is the basis of the FCC. The 1934 Communications Act and subsequent amendments regulate that anyone cannot interfere with the freedom speech. However, the FCC also must control the contents of programs about children, television violence, the authenticity of the news and political programs. For example, limit the length of advertising time of children's programs, and prohibit unfair treatment to the President, Vice President, senators and representatives and other political candidates, and so on.

\subsection{The Board of Governors of the British Broadcasting Corporation (The Board of Governors of the BBC)}

In Europe, a major feature of the British radio and television system is the relatively long history of the coexistence of the two-headed structure, the public and commercial electronic media, the public radio and television dominated by the BBC.

In 1927, the BBC obtained the license of running broadcast from the postal minister in accordance to the authorization of the Royal Charter, a private broadcasting company turning into a national company. Since 1936 (interrupted a period of 1939-1946 because of the world war), the BBC has obtained a TV operating license. The charter basis and license are replaced regularly by the government. There is an inherent nature of contact between the charter basis of the BBC and the concept of trustee. The so-called "trustee", was determined as early as 1926 that "broadcasting service should be operated by a public company as the trustee of the national interests, which the status and responsibilities should be consistent with the identity of the public service organization".(Wolfgang Hoffmann-Riem, 1996) The charter basis of the BBC make it free from the risk of revocation by any institution, except that the king published a decree that canceled its charter basis, or the Congress asked the king so, but the legal principles has never happened. The funds of the BBC comes mainly from license fees, the specific number determined by the Congress which proposed by the Minister of the Interior. The Council of the BBC is BBC's highest governing body, responsible for the development of program standards, controlling the financial planning and major decision-making, to ensure balance and diversity of the program. The president elected independently runs the company under the guidance of the Council's policy and supervision. The appropriate distinction between the Council of the $\mathrm{BBC}$ and the president is one of the keys to ensure the normal running. In the long history, the relationship between the two is equal in general. In 1996, the Charter further clarified the basic functions of the Council, which represents the public interests to ensure that the trustee status of the $\mathrm{BBC}$, to ensure that its functions as a public service. At the same time, how to play this security function has been defined, namely, focusing on regulation instead of replacing the professional works of the president. (Thomas Gibbons, 1998)

The BBC found a basic paradigm on radio and television industry of western world. In addition to the spread of freedom, fairness, pluralism, independence, diversity, an appropriate proportion of the British contents, its basic principle distinctively links to public services, journalistic professionalism and elitism.

Because of the professional spirits of the BBC, in1904, the British Radio Bill stipulates that anyone who wants to broadcast or receive radio programs must obtain a license from the Post Office. In 1971, the family broadcast receiver license was canceled, but the individual who wanted to watch television programs still had to pay for a 
license. Today, every family (except the elderly and a few low-income people, their costs are borne by the British Departments of Culture, Media and Sport) or enterprise in the UK must purchase a TV license, which the cost set by the government. As required as a public broadcaster by the government, it cannot introduce commercials and program sponsors, so television license fees and government subsidies become the sources of income. In particular, its domestic revenues are almost all from the license fees. Since the past 80 years, the license fee has been an increasing trend. In 1968, it charged $£ 10$ a year, reaching to $£ 121$ in 2005 . Its annual TV license fees amount to approximately $£ 2.8$ billion. (Tang shiding \& Li Bin, 2005 March)

\subsection{The Administration of Japanese Television System}

Terrestrial wireless television which is open free TV is the backbone of the Japanese television system with the longest history, covering almost all of the 45 million households. Depending on the running mode, terrestrial wireless television divides into two different systems which are the commercial radio and television companies relying on advertising revenues and the public broadcasters NHK relying on the subscription. The commercial radio and television companies include five companies, the TV Asahi, Tokyo Broadcasting System (TBS), Fuji TV, TV TOKYO, and Nippon Television (NTV). They owning 127 affiliated stations all relies on advertising revenues, and are distributed to 47 Roads, Houses and counties, these televisions in the television network system implementing local playback, independent establishment and program sharing. NHK, the public television, funded by the state, operates independently and transmits nationally. The subscription of the NHK is very similar to the license fee of the BBC. This subscription is to maintain the operation of public radio and television instead of the equivalent costs for watching TV programs, a special kind of costs borne by the national, which is completely different from the costs for watching pay-TV programs in nature. The Japanese Broadcasting Act clearly stipulates that the national pay the subscription. Regardless of whether watching NHK programs, families have to pay this fee. In addition, the NHK uses broadcasting satellite to transmit BSI, a news and sports channel, and BSZ, a culture and entertainment channel. National who watches these two television channels is required to pay the subscription.

Later, in 2001, Japan relaxed cable television regulation by issuing Telecommunication Service Act to the Broadcasting which provides radio and television business with telecommunication facilities, defines that broadcasting business can be transmitted in the telecommunication network. After that, telecommunication carriers do not require the Cable Act when engaged in the radio and television business. Registration can be qualified in the Ministry of Internal Affairs and Communications. Other telecommunication enterprises which receive the approval of Ministry of Internal Affairs and Communications can apply for mobile TV services, greatly lowering the threshold of accessing to the radio and television service. Radio and Television Act in the Telecommunication issued by the government, aimed at promoting the integration of communications and broadcasting transmission facilities, and relaxed the regulation of the usage of telecommunication equipments by satellite broadcasting televisions and cable televisions, making telecommunication business institutionalized. The government is developing Information and Communication Act to uniformly regulate the contents, carriers and platforms of the triple play, in order to fully adapt to the new situation.

\section{The Strategies of Government Administration in China}

\subsection{Improving relevant legislation on the pay-TV.}

Recently, China's pay-TV system is mainly in accordance with the relevant departments at all levels to develop a variety of policies, regulations, ordinances and even executive orders, administrative means and opinions. The Notices, Views, and Rules are just the regulations of the department in charge, through "issuing" instead of legislation, which lead to poor legal effect on the regulation, and lack of seriousness, authority, systematicness, foresight and stability. For example, the highest administrative regulation, Radio and Television Management Ordinance developed in 1997, now is still not amended accordingly yet even technology and pay-TV developing. Moreover, with a drastic change in the pattern of digital TV industry for several years, the business of digital pay channels moves ahead of the system construction. In 2007, when the entire conversion was vigorously launched, facing the brilliant trend of the pay-TV market, the SARFT did not introduce even one new policy for the industry. Introduced in 2003, Interim Measures of Business Management of Radio and Television Cable Digital Pay Channel (Trial) and other policies and regulations have been gradually out of line with the reality, which makes premium channels get little support and guidance from the relevant policies in the developing process. There are a number of policy gaps in the digital pay channel industry. The integration and operation are still faced with constraints and restrictions of policies, some areas having not fully market-oriented yet.

To this end, the policy administration should do the following steps: First, strengthen the formulation of relevant laws and regulations of digital pay channels. A sound legal basis is an important guarantee the government made for 
regulation. China should build up a legal system that Radio and Television Act is the pillar, based on administrative rules, supplemented local laws and regulations. Second, actively introduce policies to support the development of digital pay television. On account of the current predicament, digital pay channels as new projects of industrialization, market-oriented operation in the early stages, administrative authorities necessarily need to introduce some protection and support policies, including changes and relaxation of related policies, supporting it through the transition period of the structure and the cultivation period of the growing market. Third, implement public governance. Pay-TV is related to the interests of all aspects, so change the situation, by establishing a common governance platform of the government administration, operators, content producers, network operators, and users, effectively promoting the development of the pay-TV.

\subsection{Relaxing regulations of the advertisement and content.}

The SARFT should be modest to relax advertising controls in the early stages of the development, and to promote the survival and development of the premium channels. Under the principle, let the market judge and choose the business mode, by using the invisible hand to promote self-improvement of the pay channels. In transmitting channels, digital pay channels should be allowed to expand to other channels to broaden the profitable platform. For example, allow the programs and contents reproduced with program materials to be placed in the open channels, or in the ways of satellite televisions, Internet, mobile phones, IPTV, mobile TV and other emerging media platforms. In terms of the content, policy control is more stringent. The government should relax the introduction of overseas programs, the policies of the production of domestic digital pay-TV to support the operation and development. The state should modify the existing policies to liberalize entertainment and humanity TV programs involving political meanings, allowing broadcasting after reviewing. In fact, there are some differences between the pay channel and general channel. As to the operators, they do not really own the channel resources in the traditional sense, but is responsible for the content production. Thus this part should be deregulated further and open up to capitals to absorb more funds in participating in the construction of the content, to form a richer program market. Meanwhile, strengthen the supervision of the integration and transmission of digital pay channels and the review of channel contents, to ensure the appropriate orientation of its contents and the safety of players.

\subsection{Relaxing the entry restrictions of other capitals.}

The entry conditions of private capitals and foreign capitals are also more demanding. To ensure the ideological security, cultural security, as well as the status of national economic entity, the conditions of the capital access should be relaxed, to provide a good opportunity for private capitals to access to the digital pay-TV industry. In November, 2004, the SARFT issued Interim Provisions of Joint Ventures and Co-operations in Broadcasting Enterprises of Programs Production (referred to as Decree 44), which indicated that China had relaxed the limitations of foreign capitals to domestic broadcasting production industry. In accordance with the Decree 44, the establishment of wholly foreign-owned radio and television program production enterprises is prohibited. The maximum percentage of its shares shall not exceed $49 \%$ if foreign investment participates in establishing and operating Sino-foreign joint venture or cooperation in radio and television program enterprises. Decree 44 "opened the era of Chinese and foreign capital cooperating in the field of program production". (Zhang yonghua, 2005) China's media industry had ushered cooperation and challenge of powerful foreign capitals. However, four years after the implementation of the Decree 44, in February 6, 2009, the SARFT issued Abolition of < Interim Provisions of Joint Ventures and Co-operations in Broadcasting Enterprises of Programs Production $>$ to meet the requirements of current development. The release of this decision "makes foreign investors looking for investment opportunities in the field of film and television suddenly lost their direction". (Ming Shuliang, 2009, March 20) Such turning back is not consistent with the development of pay-TV. China's pay-TV must change the situation of over-reliance on the government, and gradually establish a media development mechanism which leaded by market allocation. Private capitals and foreign capitals with funds, resources and program advantages are encouraged to participate in co-operation to promote industrial asset structure transforming from centralization to diversity.

\subsection{Relaxing other constraints and offer policy-biased supports.}

With the popularity of Internet and mobile phone in China, a growing number of Internet users are accustomed to use computers or mobile phones and other new terminals to receive information. To this end, digital pay channel should be allowed to expand to other channels to broaden the profitable platform. For example, allow the programs and contents reproduced with program materials to be placed in the open channels, or in the ways of satellite televisions, Internet, mobile phones, IPTV, mobile TV and other emerging media platforms. In addition, preferential policies should be developed in capital investment, tax reduction, exemption, interest-free, cut and other aspects. For example, transmission costs could be cut down to reduce the running costs of digital pay channels. 


\section{References}

Jin, Guanjun \& Zhen, Han. (2007). Main Mode of Contemporary Europe and the United States National Radio and Television Administrative System. China Media Reports, vol.4.

Ming, Shuliang. (2009, March 20). Foreign Investment aimed at the Opportunities of Chinese Film and Television. [Online] Available: CAIJING.com.cn, http://www.caijing.com.cn/2009-08-20/110227523.html.

Patrick, Parsons \& Robert, Friedan. Cable and Satellite TV Industry, Beijing: Tsinghua University Press, p.252.

Robert, J. Spitzer (editor). (1993). Media and Public Policy, London: Praeger.

Tang, Shiding \& Li, Bin. (2005, March). World Television and Media Organizations, Beijing: Communication University of China Press, p.167-168.

Thomas Gibbons. (1998). Regulating the Media, London: Sweet \& Maxwell, p.249-250.

Wolfgang, Hoffmann-Riem. (1996). Regulating Media, New York and London: The Guilford Press, p.78.

Wu, Keyu. (2001). Policy Suggestions for Government Control of Television Industry in China. the Academy of Radio and Television, vol.12, p.7.

Zhang, Yonghua. (2005). Current Status and Challenges of the Foreign Media to Enter Shanghai, News Reporters, vol.6, p.3-7.

Zhao, Fei. (2011). 2003-2004 the Research of the Development of Chinese Digital Pay-TV Channels, Jinan, Doctoral dissertation of Shandong University. 